\title{
PENGARUH BRANCHED CHAIN AMINO ACIDS (BCAA) TERHADAP KEMAMPUAN MENCEGAH TERJADINYA KELELAHAN PADA PEGAWAI BAGIAN PERSONAL TRAINER DI CELEBRITY FITNESS SURAKARTA TAHUN 2020
}

\author{
Oxy Septinina ${ }^{1}$, Triyanta ${ }^{2}$, Nur Ani ${ }^{3}$ \\ 1,2,3Program Studi S1 Kesehatan Masyarakat, Fakultas Kesehatan Masyarakat, \\ Universitas Veteran Bangun Nusantara Sukoharjo, Indonesia \\ Email : ${ }^{1}$ wahyukrisna12@gmail.com \\ Email : 2triyanta2911@gmail.com \\ Email : 3aninurk3@gmail.com
}

\begin{abstract}
ABSTRAK
Branched Chain Amino Acids (BCAA) merupakan asam amino esensial yang terdiri dari 3 macam asam amino yaitu leusin, isoleusin, dan valin yang berperan dalam protein sintetis dan sistem energi pada saat aktivitas. Kelelahan adalah suatu keadaan ketika seseorang merasa lelah secara fisik atau mental. Berdasarkan ILO (2016), sebanyak 2 juta jiwa setiap tahunnya dan satu pekerja setiap 15 detik meninggal karena kecelakaan yang disebabkan faktor kelelahan. Hasil studi pendahuluan Juni 2019 di Celebrity Fitness Surakarta dilakukan survey penggunaan BCAA sebanyak 63,5\% mengkonsumsi BCAA dan sebanyak 36,5\% diantaranya tidak mengkonsumsi suplemen BCAA. Penelitian ini bertujuan untuk mengetahui pengaruh pemberian suplemen BCAA terhadap kemampuan mencegah terjadinya kelelahan pada pegawai bagian Personal Trainer di Celebrity Fitness Surakarta. Penelitian ini merupakan penelitian eksperimental analitik. Penelitian dilakukan di Celebrity Fitness Surakarta pada bulan Juli sampai Desember 2019. Sampel yang diambil sejumlah 40 orang karyawan dari total populasi karyawan 63 orang yang bekerja di departemen PT, FOH, dan MC. Teknik pengambilan sampel menggunakan purposive sampling. Variabel bebas adalah Suplemen BCAA, variabel terikat adalah kelelahan. Analisis data menggunakan t-independent dengan $a=5 \%$. Hasil analisis univariat terdiri dari 50\% kelompok kontrol (tidak mengkonsumsi suplemen BCAA) dan 50\% kelompok perlakuan (mengkonsusmsi suplemen BCAA). Hasil analisis bivariat menunjukkan nilai pretest antara kelompok kontrol dan perlakuan yaitu $\mathrm{p}=$ $0.000(\mathrm{p}<0,05)$ yang artinya ada pengaruh signifikan antara pemberian suplemen BCAA dalam kemampuan mencegah terjadinya kelelahan pada pegawai bagian personal trainer. Saran untuk perusahaan agar mengurangi budget target goal conduct setiap bulannya agar pegawai tidak memaksakan diri dengan bekerja atau mengajar lebih dari 8 jam setiap harinya. Untuk pegawai agar tidak mengkonsumsi suplemen BCAA dalam jangka waktu yang sangat lama dikarenakan belum adanya penelitian yang membuktikan efek samping pemakaian jangka panjang dari konsumsi suplemen tersebut.
\end{abstract}

Kata Kunci : asam amino, suplemen BCAA, kelelahan, pelatih personal 


\begin{abstract}
Branched Chain Amino Acids (BCAA) is an essential amino acid consisting of 3 types of amino acids, namely leucine, isoleucine, and valine which play a role in synthetic proteins and energy systems during activity. Fatigue is a condition when someone feels physically or mentally exhausted. According to ILO (2016), as many as 2 million people each year and one worker every 15 seconds are caused by accidents caused by disputes. The results of a preliminary study in June 2019 at Celebrity Fitness Surakarta conducted a survey of the use of BCAA as much as $63.5 \%$ consumed BCAA and as many as $36.5 \%$ of them did not consume BCAA supplements. This study aims to determine the effect of supplementation with Branched Chain Amino Acids (BCAA) on the ability to prevent the occurrence of fatigue in employees of the Personal Trainer section at Celebrity Fitness Surakarta. This research is an analytic experimental research. The study was conducted at Celebrity Fitness Surakarta in July to December 2019. Samples taken amounted to 40 employees from a total of 63 employees working in the departments of PT, FOH, and MC. The sampling technique uses purposive sampling. The independent variable is $B C A A$ supplement, the dependent variable is fatigue. Data analysis using $t$-independent with value $a=5 \%$. Univariate analysis results consisted of the $50 \%$ the control group (did not consume BCAA supplements) and 50\% from the treatment group (consume BCAA supplements). The results of the bivariate analysis showed the pretest value between the control and care groups that is $p=0,000$ ( $p$ $<0.05)$ which means there was a significant difference between giving BCAA supplements in increasing the ability to prevent fatigue the personal trainer employees. Suggestions for companies to reduce the budget target goal conduct each month so that employees do not force themselves to work or teach more than 8 hours every day. For employees not to consume BCAA supplements for a very long period of time due to the absence of studies that prove the side effects of long-term use of supplements.
\end{abstract}

Keyword : amino acids, supplements BCAA, fatigue, personal trainer

\section{PENDAHULUAN}

Kelelahan adalah suatu keadaan yang disertai penurunan efisiensi dan ketahanan dalam bekerja. Kelelahan merupakan mekanisme perlindungan tubuh agar tubuh menghindari kerusakan lebih lanjut (Tarwaka, 2010). Terdapat dua jenis kelelahan, yaitu kelelahan otot dan kelelahan umum. Kelelahan otot merupakan tremor pada otot atau perasaan nyeri yang terdapat pada otot. Kelelahan umum ditandai dengan berkurangnya kemauan untuk bekerja, yang sebabnya adalah persyaratan atau psikis (Suma'mur, 2014).

Latihan kekuatan merupakan komponen umum dari latihan olahraga. Selama latihan, terutama latihan eksentrik seperti latihan beban, latihan plyometric dan berlari kencang umumnya dapat menyebabkan kerusakan otot. Selain itu, dapat menyebabkan robeknya sarkolema di beberapa serat otot, miofibril yang rusak, dan rusaknya garis z. Kerusakan sel otot setelah melakukan latihan dengan intensitas yang tinggi ditandai salah satunya oleh meningkatnya kadar enzim CK (Creatine Kinase). Selain itu, kerusakan sel otot setelah melakukan latihan dengan intensitas tinggi juga ditandai oleh meningkatnya kadar enzim LDH (Lactate Dehidrogenase) dan serum myoglobin (Buckley et al. 2010).

Kerusakan otot yang terjadi setelah latihan tersebut, harus segera dipulihkan karena kerusakan otot dapat menyebabkan rasa nyeri otot dan rasa tidak nyaman yang dialami cukup lama yaitu sekitar satu sampai tiga hari setelah melakukan latihan, kondisi ini membuat seseorang menjadi sulit untuk tidur. Di samping itu, dampak kerusakan otot juga dapat menurunkan kemampuan kekuatan otot maksimal. Latihan kekuatan dapat menyebabkan rasa nyeri otot secara 
signifikan setelah 6 jam latihan (Willmore et al. 2010).

Branched chain amino acids (BCAA) atau asam amino rantai bercabang yaitu leusin, valin, dan isoleusin merupakan asam amino yang penting bagi para atlet dan individu yang aktif, karena digunakan dalam metabolisme energi dalam kerja otot. Selain itu, leusin memainkan peran penting dalam regulasi sintesis protein (Brian dan Haub 2014). Suplementasi protein telah terbukti meringankan kerusakan otot, yang ditandai dengan menurunnya kadar CK, mengurangi rasa nyeri otot serta meningkatkan fungsi otot (Millard et al. 2011).

Berdasarkan Internasional Labour Organitation (ILO, 2017) setiap tahun sebanyak dua juta pekerja meninggal dunia karena kecelakaan kerja yang disebabkan oleh faktor kelelahan kerja. Satu pekerja di dunia meninggal setiap 15 detik karena kecelakaan kerja dan 160 pekerja mengalami sakit akibat kerja. Tahun 2012 ILO mencatat angka kematian dikarenakan kecelakaan dan penyakit akibat kerja (PAK) sebanyak dua juta kasus setiap tahun.

Hasil Survei Angkatan Kerja Nasional (SEKERNAS) Badan Pusat Statistik (BPS) menunjukkan pada tahun 2018 jumlah kecelakaan 95.906, korban meninggal dunia 28.297 jiwa, luka berat 26.840, luka ringan 109.741 kerugian materi 250.021 juta rupiah, tahun 2015 jumlah kecelakaan 98.970, korban meninggal dunia 98.907, luka berat 23.937, luka ringan 10.714, kerugian materi 272.318 juta rupiah (BPS, 2018).

Data dari Jamsostek (2017), angka kecelakaan kerja setiap tahun meningkat yang disebabkan oleh berbagai faktor salah satunya kelelahan kerja. Pada tahun 2012 terdapat 98.711 kasus kecelakaan kerja, tahun 2013 terdapat 99.401 kasus kecelakaan kerja, tahun 2014 terdapat 103.074 kasus kecelakaan kerja, tahun 2015 terdapat 103.283 kasus kecelakaan kerja, tahun 2016 terdapat 3.235 kasus dan pada 2017 sebanyak 451 kasus kecelakaan kerja (Jamsostek, 2017).

Pada penelitian sebelumnya yang dilakukan oleh Muhammad Abdulhamid (2015) dengan judul Suplemen Branched Chain Amino Acids (BCAA) mampu mencegah terjadinya kelelahan pada mahasiswa pendidikan dokter UNS Surakarta menunjukkan bahwa, berdasarkan hasil uji statistik menggunakan t-independent diperoleh nilai $p$ value $=0,000(\mathrm{p}<0,05)$ yang berarti bahwa hasil uji sangat signifikan, sehingga disimpulkan bahwa suplemen BCAA mampu mencegah terjadinya kelelahan pada mahasiswa kedokteran UNS Surakarta.

Beberapa penelitian tentang pemulihan kerusakan otot yang sudah dilakukan sebelumnya menggunakan asam amino bebas seperti asam amino rantai bercabang (BCAA) adalah Matsumoto et al. (2009), Howatson et al. (2012), Jackman et al. (2010), sedangkan Street et al. (2011) menggunakan glutamin, dan Kirby et al. (2012) menggunakan asam amino leusin.

Celebrity Fitness adalah salah satu perusahaan yang bergerak dibidang olahraga dengan nama PT. Exertainment Indonesia. Celebrity Fitness merupakan klub fitness paling populer di Asia Tenggara dan klub fitness dengan pertumbuhan tercepat. Sampai saat ini Celebrity Fitness sudah memiliki lebih dari 200.000 anggota aktif dan lebih dari 60 klub di Indonesia, Malaysia, Singapura dan India. Celebrity Fitness kini memimpin pasar fitness Indonesia dengan jaringan di 11 kota dari Medan sampai Bali dan di mall-mall strategis di Indonesia salah satunya di Solo Paragon yang terletak di Banjarsari Surakarta. Celebrity Fitness memiliki beberapa departemen yaitu Personal Trainer (PT) sebagai pelatih bagi setiap member yang menginginkan body goals tertentu, Front of House (FoH) bagian administrasi, Membership Consultant (MC) bagian mencari membership baru dan Group Fitness sebagai instructur dalam setiap 
kelas yang ada diantaranya Zumba class, Bodypupm, Bodycombat dan masih banyak lagi.

Hasil studi pendahuluan yang dilakukan pada tanggal 15 Juni 2019 di Celebrity Fitness Surakarta dari jumlah 63 pegawai yang dilakukan survey penggunaan BCAA, terdapat 40 staff atau sebanyak $63,5 \%$ mengkonsumsi BCAA dan 23 staff atau sebanyak $36,5 \%$ diantaranya tidak mengkonsumsi suplemen BCAA. Berdasarkan wawancara dengan staff yang mengkonsumsi suplemen BCAA, mereka menyatakan bahwa konsumsi suplemen tersebut ditujukan untuk membantu mengatasi kelelahan dan nyeri otot yang mereka alami ketika banyak melakukan aktivitas fisik berat. Mereka juga menyebutkan bahwa, konsumsi suplemen ini seperti sudah menjadi suatu kebutuhan bagi mereka karena selain aktivitas berat berupa olahraga dan latihan fisik yang lain mereka juga harus memberikan pelatihan terhadap para member yang memiliki sesi pertemuan setiap harinya. Bahkan dalam sehari mereka bisa memberikan latihan fisik terhdap member lebih dari 8 jam sehari. Selain itu intensitas kerja, aktifitas fisik dan latihan yang cukup tinggi, membuat tubuh sangat mudah lelah jika tidak diimbangi dengan olahraga rutin dan konsumsi makanan yang seimbang serta multivitamin.

Berdasarkan beberapa faktor penyebab kelelahan kerja di atas menunjukkan bahwa kelelahan kerja merupakan salah satu sumber masalah bagi kesehatan dan keselamatan pekerja. Kelelahan dapat menurunkan kinerja dan menambah tingkat kesalahan kerja yang akan berpeluang menimbulkan kecelakaan kerja. Tentu saja hal ini tidak dapat dibiarkan begitu saja, karena tenaga kerja merupakan aset perusahaan yang dapat mempengaruhi produktivitas perusahaan

Berdasarkan uraian di atas, maka penulis tertarik melakukan penelitian mengenai pengaruh suplemen BCAA terhadap kemampuan mencegah terjadinya kelelahan pada pegawai Celebrity Fitness Surakarta.

\section{METODE PENELITIAN}

Penelitian ini bersifat eksperimental analitik dengan the pretest postest group design. Analisis pada penelitian the pretest postest group design bermaksud untuk melihat adanya perbedaan antara variabel terikat sebelum dan sesudah perlakuan dimana peneliti melihat adanya pengaruh pemberian suplemen BCAA terhadap kemampuan mencegah terjadinya kelelahan pada pegawai Celebrity Fitness Surakarta. Penelitian ini menggunakan the pretest postest group design, maka dalam pengamatan terhadap sampel perlakuan dilakukan dua kali.

Populasi dari penelitian ini adalah pegawai Celebrity Fitness Surakarta sebanyak 63 orang, dan sampel didapatkan dengan menggunakan teknik purposive sampling sebanyak 40 orang. Subjek dibagi menjadi 2 kelompok yaitu kelompok perlakuan dan kelompok kontrol. Masing-maisng kelompok terdapat 20 responden yang dipilih secara random.

Instrumen pada penelitian ini adalah alat reaction timer tipe L.77 Lakaassidaya, suplemen BCAA, timbangan berat badan, microtoice, treadmill, bosu, sandbell slam, dan kettlebell swing.

Analisis data yang digunakan adalah analisis secara analitik dengan uji tindependent menggunakan program SPSS 17.

\section{HASIL DAN PEMBAHASAN}

3.1. Gambaran Umum Celebrity Fitness Surakarta

Celebrity Fitness Solo Paragon merupakan tempat olahraga terbesar seAsia Tenggara yang dinaungi oleh perusahaan PT. Exertainment Indonesia. Celebrity Fitness Solo terletak di Jl. Yosoipuro No 133 Kec. Banjarsari Kel. Mangkubumen Surakarta. Club ini berdiri di Solo sejak bulan Desember 
2016, sampai saat ini Celebrity Fitness sudah memiliki lebih dari 170.000 anggota aktif dan lebih dari $60 \mathrm{klub}$ di Indonesia, Malaysia, Singapura dan India. Celebrity Fitness kini memimpin pasar fitness Indonesia dengan jaringan di 11 kota dari Medan sampai Bali dan di mall-mall strategis di Indonesia salah satunya di Solo Paragon yang terletak di Banjarsari Surakarta. Celebrity Fitness memiliki beberapa departemen yaitu Personal Trainer sebagai pelatih bagi setiap member yang menginginkan body goals tertentu, Front of House bagian administrasi, Membership Consultant bagian new join membership dan Group Fitness sebagai instructur dalam setiap kelas yang ada diantaranya Zumba, Bodypupm, Bodycombat dan masih banyak lagi.

\subsection{Karakteristik Responden}

Responden sejumlah 40 orang berasal dari kelompok kontrol dan perlakuan khususnya bagian Personal Trainer di Celebrity Fitness Solo diperoleh data sebagai berikut

Tabel 1. Distribusi Responden Berdasarkan Usia, Masa Kerja, dan Indeks Masa Tubuh (IMT)

\begin{tabular}{|c|c|c|c|c|c|}
\hline \multirow[t]{3}{*}{ No } & \multirow[t]{3}{*}{ Variabel } & \multicolumn{4}{|c|}{ Kelompok } \\
\hline & & \multicolumn{2}{|c|}{$\begin{array}{c}\text { Kontrol } \\
(n=20)\end{array}$} & \multicolumn{2}{|c|}{ Perlakuan $(n=20)$} \\
\hline & & $\mathbf{N}$ & $\%$ & $\mathbf{N}$ & $\%$ \\
\hline \multirow[t]{4}{*}{1} & Usia (tahun): & & & & \\
\hline & a. $20-24$ & 8 & $(27,5)$ & 7 & $(25,0)$ \\
\hline & b. $25-29$ & 11 & $(20,0)$ & 10 & $(17,5)$ \\
\hline & c. $30-34$ & 1 & $(2,5)$ & 3 & $(7,5)$ \\
\hline \multirow[t]{4}{*}{2} & Masa Kerja (bulan): & & & & \\
\hline & a. $1-<2$ & 3 & $(7,5)$ & 2 & $(5,0)$ \\
\hline & b. $\geq 2-<3$ & 11 & $(27,5)$ & 10 & $(20,0)$ \\
\hline & c. $\geq 3-4$ & 6 & $(15,0)$ & 8 & $(20,0)$ \\
\hline \multirow[t]{5}{*}{3} & IMT & & & & \\
\hline & a. 19 & 1 & $(2,5)$ & 2 & $(5,0)$ \\
\hline & b. 20 & 4 & $(10.0)$ & 4 & $(10,0)$ \\
\hline & c. 21 & 9 & $(22,5)$ & 4 & $(10,0)$ \\
\hline & d. 22 & 6 & $(15,0)$ & 10 & $(25,0)$ \\
\hline
\end{tabular}

Sumber: Data Primer, Januari 2020

Berdasarkan tabel 1 diatas hasil observasi terhadap 40 pekerja personal trainer laki-laki didapatkan hasil bahwa, sebagian besar pegawai berumur 25-29 tahun yaitu sebanyak 11 orang $(20,0 \%)$ pada kelompok kontrol, dan sebanyak 10 pegawai $(17,5 \%)$ pada kelompok perlakuan. Sedangkan, paling sedikit adalah usia dengan rata-rata 30-34 tahun yaitu 1 orang $(2,5 \%)$ untuk kelompok kontrol dan 3 orang (7,5\%) untuk kelompok perlakuan.

Pada tabel tersebut menunjukkan bahwa, persentase tertinggi masa kerja pegawai lak-laki personal trainer Celebrity Fitness adalah $\geq 2-<3$ tahun sebanyak 11 orang $(27,5 \%)$ pada kelompok kontrol dan 10 orang pegawai $(10,0 \%)$ pada kelompok perlakuan. Sedangkan untuk persentase masa kerja terendah adalah $1-<2$ tahun dengan 3 orang $(7,5 \%)$ pada kelompok kontrol dan 2 orang $(5,0 \%)$ pada kelompok perlakuan.

Kemudian dilihat dari hasil IMT (Indeks masa tubuh) pada 40 pegawai personal trainer laki-laki Celebrity Fitness secara keseluruhan memiliki rata-rata Indeks Masa Tubuh yang normal yaitu antara 18,5 - 22,9. Persentase tertinggi 
terdapat pada angka IMT 21 yaitu sebanyak 9 orang $(22,5 \%)$ pada kelompok kontrol dan nilai IMT tertinggi selanjutnya pada angka 22 yaitu sebanyak 10 orang $(25,0 \%)$ pada kelompok perlakuan. Sedangkan untuk persentase terendah nilai IMT pada angka 19 yaitu sebanyak 1 orang $(2,5 \%)$ pada kelompok kontrol dan 2 orang $(5,0 \%)$ pada kelompok perlakuan.

\subsection{Analisi Univariat}

Analisis univariat menghasilkan distribusi dan persentase dari tiap variabel. Analisis ini dilakukan untuk mendeskripsikan variabel penelitian dengan membuat tabel ditribusi frekuensi dan sebaran data dalam bentuk tabel.

Dsitribusi hasil penelitian berdasarkan observasi konsumsi suplemen BCAA sebelum dilakukan serangkaian tes terhadap staff Personal Trainer di Celebrity Fitness Surakarta dapat dilihat pada tabel di bawah ini :

Tabel 2. Ditribusi Frekuensi Responden Berdasarkan Konsumsi Suplemen BCAA

\begin{tabular}{|c|c|c|c|c|c|}
\hline \multirow{3}{*}{ No } & \multirow{3}{*}{ Variabel } & \multicolumn{4}{|c|}{ Kelompok } \\
\hline & & \multicolumn{2}{|c|}{$\begin{array}{l}\text { Kontrol } \\
(\mathrm{n}=20)\end{array}$} & \multicolumn{2}{|c|}{$\begin{array}{c}\text { Perlakuan } \\
(n=20)\end{array}$} \\
\hline & & $\mathbf{N}$ & $\%$ & $\mathbf{N}$ & $\%$ \\
\hline 1 & Diminum & 0 & 0,0 & 20 & 50,0 \\
\hline 2 & $\begin{array}{l}\text { Tidak } \\
\text { Diminum }\end{array}$ & 20 & 50,0 & 0 & 0,0 \\
\hline
\end{tabular}

Personal Trainer didapatkan hasil bahwa seluruh responden kelompok perlakuan sebanyak 20 orang $(50 \%)$ meminum suplemen BCAA yang diberikan sebelum dilakukan tes fisik dan uji kelelahan, sedangkan seluruh responden kelompok kontrol sebanyak 20 orang (50\%) tidak meminum suplemen BCAA.

Suplemen BCAA yang diberikan adalah jenis suplemen Muscle Pharm sebanyak 6 gram atau setara 8 kapsul dalam sekali minum. Suplemen BCAA diberikan 25 menit sebelum serangkaian tes diberikan, kemudian seluruh responden diberikan arahan dan instruksi mengenai tes yang akan dilakukan. Selanjutnya responden kelompok perlakuan mengkonsumsi suplemen BCAA dan setelah 10 menit berlalu seluruh responden baik kelompok kontrol maupun perlakuan mengikuti tes fisik selama 30 menit dan bekerja selama 30 menit kemudian mengikuti uji kelelahan menggunakan alat reaction timer.

Distribusi hasil penelitian berdasarkan pengukuran tingkat kelelahan pada pegawai Personal Trainer di Celebrity Fitness dapat dilihat pada tabel dibawah ini :

Sumber : Data Primer, Januari 2020

Berdasarkan tabel 2 diatas hasil observasi terhadap 40 pegawai staff

Tabel 3. Disribusi Frekuensi Responden Berdasarkan Tingkat Kelelahan

\begin{tabular}{llccccc}
\hline \multirow{2}{*}{ No } & \multicolumn{1}{c}{ Variabel } & $\begin{array}{c}\text { Waktu } \\
\text { Reaksi }\end{array}$ & \multicolumn{2}{c}{$\begin{array}{c}\text { Kontrol } \\
(\mathbf{n = 2 0 )}\end{array}$} & $\begin{array}{c}\text { Kelompok } \\
\text { Perlakuan } \\
(\mathbf{n = 2 0 )}\end{array}$ \\
\cline { 3 - 7 } & & $\mathbf{N}$ & $\mathbf{\%}$ & $\mathbf{N}$ & $\mathbf{\%}$ \\
\hline 1 & Tingkat Kelelahan Pretest & & & & & \\
& a. Normal & $150-240$ & 20 & 50,0 & 20 & 50,0 \\
& b. Kelelahan Kerja Ringan & $>240-<410$ & 0 & 0,0 & 0 & 0,0 \\
& c. Kelelahan Kerja Sedang & $410-<580$ & 0 & 0,0 & 0 & 0,0 \\
& d. Kelelahan Kerja Berat & 580 & 0 & 0,0 & 0 & 0,0 \\
\hline 2 & Tingkat Kelelahan Posttest & & & & & \\
& a. Normal & $150-240$ & 0 & 0,0 & 0 & 0,0 \\
& b. Kelelahan Kerja Ringan & $>240-<410$ & 0 & 0,0 & 20 & $\mathbf{5 0 , 0}$ \\
& c. Kelelahan Kerja Sedang & $410-<580$ & 20 & $\mathbf{5 0 , 0}$ & 0 & 0.0 \\
& d. Kelelahan Kerja Berat & 580 & 0 & 0,0 & 0 & 0,0 \\
\hline
\end{tabular}


Sumber : Data Primer, Januari 2020

Berdasarkan tabel 3 diatas hasil pengukuran tingkat kelelahan pada 40 pegawai staff Personal Trainer di Celebrity Fitness didapatkan kategori lelah normal pada seluruh responden yaitu $20(50,0 \%)$ pada kelompok kontrol dan $20(50,0 \%)$ pada kelompok perlakuan sebelum diberikan suplemen BCAA dan tes dilakukan (pretest), sedangkan setelah suplemen BCAA diberikan dan tes dilakukan (posttest) menunjukkan kategori lelah ringan pada kelompok kontrol (50\%) dan kategori lelah sedang pada kelompok perlakuan (50\%).

\subsection{Analisis Bivariat}

Analisis bivariat dilakukan untuk mengetahui ada tidaknya pengaruh pemberian suplemen BCAA terhadap kemampuan mencgah terjadinya kelelahan pada karyawan Celebrity Fitness Surakarta. Analisis bivariat menggunakan uji $t$ - independen yang dilakukan uji normalitas data terlebih dahulu dengan Saphiro - Wilk test.

Distribusi hasil penelitian berdasarkan pengukuran tingkat homogen kelelahan di Celebrity Fitness Surakarta dapat dilihat pada tabel dibawah ini :

\begin{tabular}{|c|c|c|c|}
\hline & $\begin{array}{lr}1 & \text { Dis } \\
\text { nalitas } & \text { Data }\end{array}$ & $\begin{array}{rr}\text { ssi } & \text { Be } \\
\text { an } & S a p l\end{array}$ & $\begin{array}{l}\text { dasarkan } \\
o-W i l k\end{array}$ \\
\hline No & Jenis Data & $\begin{array}{l}\text { Nilai } p \\
\text { value }\end{array}$ & $\begin{array}{l}\text { Keteranga } \\
\mathrm{n}\end{array}$ \\
\hline 1 & $\begin{array}{c}\text { Data Pretest } \\
\text { a. Kontrol } \\
\text { b. Perlakuan }\end{array}$ & $\begin{array}{l}0.207 \\
0,058\end{array}$ & $\begin{array}{l}\text { Normal } \\
\text { Normal }\end{array}$ \\
\hline 2 & $\begin{array}{cl}\text { Data Posttest } \\
\text { a. Kontrol } \\
b . & \text { Perlakuan }\end{array}$ & $\begin{array}{l}0.070 \\
0,209\end{array}$ & $\begin{array}{l}\text { Normal } \\
\text { Normal }\end{array}$ \\
\hline
\end{tabular}

Sumber : Data Primer, Januari 2020

Tabel 4 diatas menunjukkan bahwa nilai $\mathrm{p}$ kontrol pretest adalah $0.207 \quad$ (p $>0,05)$, sedangkan $\mathrm{p}$ perlakuan adalah 0.058 ( $\mathrm{p}>0,05)$, maka dapat disimpulkan bahwa kedua data pretest terdistribusi normal. Sedangkan pada data postest $\mathrm{p}$ kontrol adalah $0.070 \quad(\mathrm{p}>0,05)$, dan $\mathrm{p}$ perlakuan adalah 0.209 ( $\mathrm{p}>0,05)$, sehingga dapat disimpulkan bahwa kedua data postest terdistribusi normal. Maka dalam hal ini dapat digunakan uji $t$ independent.

Distribusi hasil penelitian berdasarkan pengaruh pemberian suplemen BCAA terhadap tingkat kelelahan pegawai Personal Trainer di Celebrity Fitness Surakarta dapat dilihat pada tabel dibawah ini :

Tabel 5. Distribusi Pengaruh Pemberian Suplemen BCAA Terhadap Kelelahan Pada Pegawai Celebrity Fitness

\begin{tabular}{cllll}
\hline No & $\begin{array}{l}\text { Jenis } \\
\text { Data }\end{array}$ & Kntrol & Perlakuan & $\begin{array}{l}\boldsymbol{P} \\
\text { value }\end{array}$ \\
\hline 1 & Pretset & $\begin{array}{l}204.0750 \pm \\
4.88931\end{array}$ & $\begin{array}{l}\mathbf{2 0 3 . 3 0 5 0} \pm \\
\mathbf{5 . 5 8 2 2 2}\end{array}$ & 0.918 \\
\hline 2 & Posttest & $\begin{array}{l}499.7650 \pm \\
297.5300 \pm\end{array}$ & 0.000 \\
& & 11.11293 & 9.41494 & \\
\hline
\end{tabular}

Sumber : Data Primer, Januari 2020

Hasil uji t-independent menunjukkan nilai $\mathrm{p}$ pada data pretest yang diperoleh 0.918 ( $p>0,05)$ yang menyatakan tidak ada perbedaan yang signifikan antara kelompok kontrol dan perlakuan. Hasil ini membuktikan bahwa keadaan sampel sudah homogen saat pretest. Sedangkan nilai $\mathrm{p}$ pada data posttest yang diperoleh adalah $0.000(p<0,05)$ yang menunjukkan terdapat perbedaan yang signifikan antara kelompok kontrol dan perlakuan maka dapat disimpulkan bahwa Ho ditolak dan $\mathrm{Ha}$ diterima. Hasil ini membuktikan bahwa ada pengaruh yang signifikan antara pemberian suplemen BCAA terhadap tingkat kelelahan pada kelompok pegawai di Celebrity Fitness.

\subsection{Pembahasan}

Penelitian ini menunjukkan bahwa karakteristsik responden pada pegawai Personal Trainer di Celebrity Fitness Surakarta ditemukan sebanyak 20 orang (50.50\%) mengalami lelah ringan pada kelompok perlakuan dan sebanyak 20 orang $(50.0 \%)$ mengalami lelah sedang yaitu pada kelompok kontrol setelah 
dilakukan post test. Perbedaan tingkat kelelahan tersebut dipengaruhi oleh pemberian suplemen BCAA sebanyak 6 gram yang bekerja 10 menit setelah dikonsumsi.

Pada penelitian Blomstrand (2010) menunjukkan bahwa suplementasi BCAA $20 \mathrm{mg} / \mathrm{kg}$ BB yang diberikan secara intravena kepada tikus terbukti mampu mencegah pelelepasan 5-hidroksitriptamine oleh otak, sehingga kadar 5hidroksitriptamine di sirkulasi menurun. Dalam penelitian ini, suplementasi BCAA diberikan $77 \mathrm{mg} / \mathrm{kg}$ BB secara oral kepada sampel mahasiswa juga mampu mereduksi kelelahan dengan meningkatkan kadar BCAA dala sirkulasi, memperkecil rasio tryptophan/BCAA dalam darah, sehingga uptake tryptophan ke otak pun berkurang, tidak terjadi sintetis dan pelepasan 5-hidroksitriptamine oleh otak, kadarnya dalam darah pun menurun.

Pada analisis data kelompok kontrol dan perlakuan saat posttest memperoleh hasil $\mathrm{p}<0,05$ (tabel 5.), menunjukkan adanya perbedaan yang signifikan. Selain karena akibat pemberian suplemen BCAA, hal ini juga bisa terjadi karena kelompok kontrol menunggu selama 10 menit dengan berisitirahat. Kelelahan bisa berkurang dengan beristirahat biasa atau tidur makan, minum dan juga perbaikan sirkulasi darah di antaranya memijat bagian tubuh yang lelah, menggosok dengan minyak hangat, dan mandi air hangat. Hal ini menegaskan bahwa penelitian ini sesuai dengan hipotesis di awal, bahwa ada pengaruh suplementasi BCAA terhadap kelelahan. Pemberian suplemen BCAA mampu memperkecil rasio tryptophan/ BCAA dalam plasma. Ketika rasio tryptophan/ BCAA mengecil, uptake triptophan ke otak juga berkurang, dan tidak terjadi sintesis serta pelepasan 5-HT, sehingga mampu mempengaruhi kelelahan.

Pada penelitian sebelumnya oleh Markus et al. (2005), penelitian ini menunjukkan bahwa dalam pemberian 3,6 gram asam amino kombinasi yang berisi isolate leusin, isoleusin, dan valin pada pagi hari dan sore hari dapat meningkatkan kadar sel darah merah dan hemoglobin. Peningkatan sel darah merah akan menyebabkan peningkatan oxygencarrying capacity sehingga terjadi kenaikan nilai VO2 max. VO2 max merupakan salah satu faktor yang mempengaruhi kelelahan. Selain peningkatan kadar sel darah merah, faktor yang mempengaruhi peningkatan VO2 max ada fungsi kardiovaskuler, fungsi paru, hereditas, usia jenis kelamin, komposisi tubuh, dan intensitas latihan.

Berdasarkan penelitian yang dilakukan oleh Van Hall (2002), disebutkan bahwa BCAA yang diberikan secara intravena dengan dosis tinggi 18 gram/liter terbukti mampu mencegah uptake berlebih trytophan oleh otak pada manusia yang sedang berolahraga. Teori yang mendasari waktu yang tepat untuk memberikan suplemen BCAA berdasarkan pada penelitian yang dilakukan Shimomura et al (2006), asam amino diberikan 10 menit sebelum diteiti, karena kadar puncak dalam darah dicapai dalam 10 menit pasca pemberian.

\section{KESIMPULAN}

Berdasarkan penelitian yang telah dilakukan pada 40 pegawai staff Celebrity Fitness Surakarta bagian Personal Trainer tahun 2020 dapat disimpulkan sebagai berikut :

Suplemen yang dikonsumsi pegawai bagian Personal Trainer Celebrity Fitness Surakarta adalah sebanyak 6 gram dalam satu kali konsumsi. Jumlah kapsul yang harus dikonsumsi adalah 8 kapsul. Dalam takarannya satu kali konsumsi atau perserving mengandung $3000 \mathrm{mg}$ leusin, 2000 mg valin, dan 1000 mg isoleusin.

Pegawai bagian Personal Trainer Celebrity Fitness Surakarta sebanyak 50,0\% mengalami kelelahan ringan pada kelompok perlakuan yang mendekati normal dan sebanyak $50,0 \%$ pegawai mengalami kelelahan sedang mendekati berat pada kelompok kontrol setelah dilakukan serangkaian tes berupa latihan 
fisik berat selama 30 menit dan bekerja selama 30 menit. Perbedaan tingkat kelelahan pada setiap kelompok dikarenakan ada dan tidaknya perlakuan yang diberikan yaitu berupa pemberian suplemen BCAA sebelum dilaksanaan serangkaian tes, sehingga pada penelitian kali ini kelompok perlakuan mengalami tingkat kelelahan yang lebih ringan dibandingkan dengan kelompok kontrol.

Ada pengaruh yang signifikan anatara pemberian suplemen BCAA terhadap kemampuan pencegahan terjadinya kelelahan pada pegawai bagian Personal Trainer di Celebrity Fitness Surakarta $(p=0,000)$.

\section{UCAPAN TERIMAKASIH}

Alhamdulillah., segala Puji syukur penulis panjatkan kehadirat Allah SWT yang telah melimpahkan Rahmat, Hidayah dan Inayah-Nya sehingga penulis dapat menyelesaikan penelitian ini dengan baik. Tak lupa kami ucapkan banyak terimakasih atas bantuan, dukungan dan doa dari berbagai pihak. Pada kesempatan kali ini dengan segala hormat kami ucapkan terimakasih khususnya kepada:

a. Prof. Dr. Ir. Ali Mursyid Wahyu Mulyono, M.P. selaku Rektor Univet Bantara Sukoharjo.

b. Titik Haryanti, S.K.M., M.P.H. selaku Dekan Fakultas Kesehatan Masyarakat Univet Bantara Sukoharjo.

c. Nine Elissa Maharani, S.K.M., M.Kes. selaku Ketua Program Studi S1 Kesehatan Masyarakat FKM Univet Bantara Sukoharjo.

d. Bapak/Ibu Dosen Fakultas Kesehatan Masyarakat Univet Bantara Sukoharjo.

\section{DAFTAR PUSTAKA}

Tarwaka. (2010). Dasar - Dasar Pengetahuan Ergonomi dan Aplikasi di Tempat Kerja. Solo: Harapan Press Solo.
Suma'mur. (2014). Higiene Perusahaan dan Keselamatan Kerja. Jakarta : Agungseto.

Buckley JD, Thomson RL, Coates AM, Howe PR, Denichilo MO, Rowney MK. (2010). Supplementation with a whey protein hydrolysate enhances recovery of muscle force-generating capacity following eccentric exercise. J Sci Med Sport. 13(1) :178-81.

Willmore, JH dan DL Costill. (2010). Physiolohy of Sport and Exercise Human Kineti., Windsor : Canada.

Millard, William D et al. (2011). Essentials of Exercise Physiology. USA : William and Wilkins.

Abdulhamid, M. (2015). Suplemen Branched Chain Amino Acids (BCAA) Mampu Mencegah Terjadinya Kelelahan pada Mahasiswa Pendidikan Dokter Universitas Sebelas Maret (Doctoral dissertation, Universitas Sebelas Maret). Surakarta: UNS.

International Labour Organitation. (2017). Keselamatan dan Kesehatan Kerja (sarana produktivitas). Jakarta : PT. Pustaka Binaman Preitido.

Kirby, TJ. Triplett NT, Haines TL, Skinner JW, Fairbrother KR, McBride JM. (2012). Effect of leucine supplementation on indices of muscle damage following drop jumps and resistance exercise Amino Acids. 42: 1987-1996.

Matsumoto K, Koba T, Hamada K, Sakura M, Higughi T, Miyata H. (2009). Branched-chain amino acid supplementation attenuates muscle soreness, muscle damage and inflammation during an intensive training program. J Sports med phys fitness. 49: 424-31.

Howatson G, Hoad M, Goodall S, Tallent J, Bell PG, French DN. (2012). Exerciseinduced muscle damage is reduced in resistance-trained males by branched chain amino acids: a randomized, double-blind, placebo controlled study. Journal of the International Society of Sports Nutrition. 9 (20):1-7. 
IAKMI Jurnal Kesehatan Masyarakat Indonesia, Volume 1, No. 1, April 2020

Journal Homepage : http://jurnal.iakmi.id/index.php/IJKMI

ISSN 2721-9437 (Media Online)

Jackman SR, Witard OC, Jeukendrup AE, Tipton KD. (2010). Branchedchain amino acid ingestion can ameliorate soreness from eccentric exercise. Medicine Science Sports Exercise. 42:962-970.

Blomstrand, E., \& Saltin, B. (2010). BCAA intake affects protein metabolism in muscle after but not during exercise in humans. American Journal of PhysiologyEndocrinology And Metabolism, 281(2), E365-E374. 